\title{
Assesment of the Behaviour and Investment Preference of Women Cassava Processors in Ekiti State, Nigeria
}

\author{
Foluso Osundare \\ Department of Agricultural Economics and Extension Services, Ekiti State University \\ Ado - Ekiti, Nigeria \\ E-mail: temidayoolowoyeye1@gmail.com \\ Temidayo Olowoyeye (Corresponding author) \\ Department of Agricultural Economics and Extension Services, Ekiti State University \\ Ado - Ekiti, Nigeria
}

Received: July 10, 2018 Accepted: August 2, 2018 Published: August 25, 2018

doi:10.5296/ijssr.v6i2.12682 URL: http://dx.doi.org/10.5296/ijssr.v6i2.12682

\begin{abstract}
The behavior and pattern of investment of cassava processors depends largely on their level of income; the need to assess their investment preference necessitated this study. The research was carried out in Ekiti State Nigeria to describe the socioeconomic characteristics of women cassava processors; examine their investment patterns; determine their propensities to invest and; analyze the factors influencing their investment decision. Information was obtained from a total of 180 women cassava processors through a well-structured questionnaire. A multi-stage sampling technique was used in the selection of respondents. The analytical tools employed were descriptive statistics, Friedman ranking analysis, and Probit regression analysis. The study showed that the mean annual income and investment of respondents were $\$ 488,750$ and $\$ 164,300$ respectively with marginal propensity to invest for every income generated at $\$ 0.228$. The Probit regression analysis showed that the major factors influencing the respondents' decision to invest in the study area were household size, annual income and return on investment. The studies showed that investment potential not only exists among the women cassava processor in the study area, they were actually investing, but their unwillingness to invest in processing equipment is worrisome. It's therefore recommended that modern processing facilities should be subsidized to reduce the processing cost,
\end{abstract}


encourage future investment on them, reduce drudgery, increase value addition, income and consequently increased investment. Secondly, soft loans free of collateral should be giving to the processors to facilitate purchase of processing equipment, develop and expand their processing sheds.

Keywords: investment preference, investment decisions, Annual income

\section{Introduction}

Cassava plays a particularly important role in the agriculture of developing countries, especially in sub-Saharan Africa which according to FAO 2004 Nigeria is the largest producer in the world. It is a food security crop which serves both as subsistence and cash crop to poor resource farmers (FAO, 2003). The uniqueness of cassava lies in its ability to survive harsh weather and can be processed into many forms like Garri, Fufu, Tapioca, Starch and partly used for Bread. It's attractive to women as a source of living, cassava stems are also sold for money as planting materials. All these have made it a global demand by individuals and industries thus making it a source of income generation for its active producers and processors who dwell in rural areas where there are vast opportunities for agricultural investment. Despite the income generated from processed cassava by its women processors, it is observed that they mostly make use of traditional technological methods of processing which most cases leads to low product quality, short shelf life, makes the processing labour-intensive and increases drudgery thereby discouraging the processors as they grow older. It's imperative that these processors should be encouraged to invest particularly on modern processing technologies so that their income generated and their interest could be sustained. Its worrisome therefore that policymakers have not really drawn up adequate and comprehensive investment scheme that will persuade the farmers to invest their capital productively. Thus, the research tends to answer the following questions: do these women cassava processors invest? If yes, what are their choices of investment? What are the factors influencing their investment decision? Does any relationship exist between their marginal propensity to save and the marginal propensity to invest? What are the constraints to their investment of these women cassava processors? Based on these problems, the broad objective of the study is to assess the behaviour and investment preference of women cassava processors in Ekiti State; the specific objectives are to:

\footnotetext{
i. describe the socio-economic characteristics of women cassava processors

ii. examine their investment patterns

iii. determine their propensities to invest and

iv. analyse the factors influencing their investment decision.
}

Investment as described by Jhingan (1997) is the production or acquisition of real capital assets any period or time. According to Ajayi (1998) investment could be considered as an act of laying out money now, in return for a future financial reward or the sacrifice of something now, for the prospect of later benefits. The reward of the above view may be received in the form of an income flow or by the receipt of a single capital sum or a combination of both. Investment adds to capital equipment and leads to increase in the level of income and production by increasing the production and purchase of capital goods (Jhingan, 1997). The 
ability, willingness and opportunity of farmers to invest overtime can therefore significantly influence the rate and sustainability of capital acquisition leading to economic growth (Oluwakemi, 2012). The behaviour and pattern of investment of small holders' farms depends largely on their level of income. It is the level of income that determines the volume of savings and therefore account for the amount of capital that could be channeled to investment.

Odoemenum Ezihe and Akerele, (2013) were of the viewed that small scale farmers invest their savings in two major areas; these are the agricultural sector and the non-agricultural sectors. Investment in the agricultural sector or farm activities includes the purchase of fertilizers and chemicals, hired labour and buying more land for farming. On the other hands, investment in non-agricultural sector mainly centered on education, trade expansion, building houses, dowry obligations and purchase of durable assets. According to him, it could further be pointed out that, two elements are fundamental to understanding of investment. First is the anticipated return which is easier to perceive and measure. Second is the risk which is a difficult concept to perceive and thus possess serious conceptual and analytical problems in terms of measurement. Consequently, many farmers in Nigeria could not access funds necessary to boost their production, thus hampers their growth and development.

Singh (2011) examined the determinants of saving and investment in rural area of Manipur and compared with Marups and how to increase rural household saving and investment. The study found that the main determinant of saving and investment are commercial banks, post office and insurance and government securities. Bairagi and Rastogi (2013) analysed the investment preferences and saving pattern of the individual household in Pune city. The study found that there are bank deposits as their main preference of investment and income influences investor awareness. Uchedu (1993) examined the impact of policy reversal on investment in the Nigerian economy. The econometric investigation of this study revealed that gross domestic investment is negatively and significantly related to prime lending rate. Oluwasola, Kassali and Amusan, (2012) in a study on factors enhancing investment and farm capitalization in small holdings in Nigeria pointed out that the low productivity, low income and low saving circle of farmers in Nigeria, as in most countries in the Sub-Saharan African region, implies that very little is available to invest in increasing the capital stock of farm enterprises. Philip, Okeke, and Mbanasor (2015) analysed the factors influencing savings and investment behaviour among yam entrepreneurs in Benue state, Nigeria using frequency distributions table, percentages and Multiple regression analysis, the results reveal that yam entrepreneurs carry out their savings on weekly basis and their investment on a daily and weekly basis. The results also indicate that financial and social factors significantly affect savings and investment behaviour of yam entrepreneurs. It was recommended that policies aimed at improving savings and investment of yam entrepreneurs should focus on social and financial factors affecting their savings and investment behaviour; campaign promoting savings and investment should be intensified; establishment of agricultural development banks and setting up more branches of commercial banks in the areas of these yam entrepreneurs should be encouraged. 


\section{Macrothink}

\section{Methodology}

\subsection{The Study Area}

This study was carried out in Ekiti State, Nigeria. The state lies entirely within the tropics is located between latitude $7 \mathrm{o} 15^{\prime}$ to $8 \mathrm{o} 5^{\prime}$ 'North of the equator and Longitude 4o $45^{\prime}$ to $5 \mathrm{o} 45^{\prime}$ East of the Greenwich meridian. It enjoys a typical tropical climate with two distinct seasons, the rainy season which last roughly from April to October and the dry season which prevails for the remaining months of the year (NAERLS and NPAFS, 2010). Ekiti is basically an agrarian society with a land area of about 5,307 square kilometres of which over $90 \%$ is available for farming and agricultural related enterprises (NAERLS and NPAFS, 2010). Equally, the state is endowed with favourable agro climatic conditions suitable for production of both tree and arable crops. The vegetation is tropical rainforest in the southern areas like Ikere, Ilawe, Ise and savannah in the Northern parts.

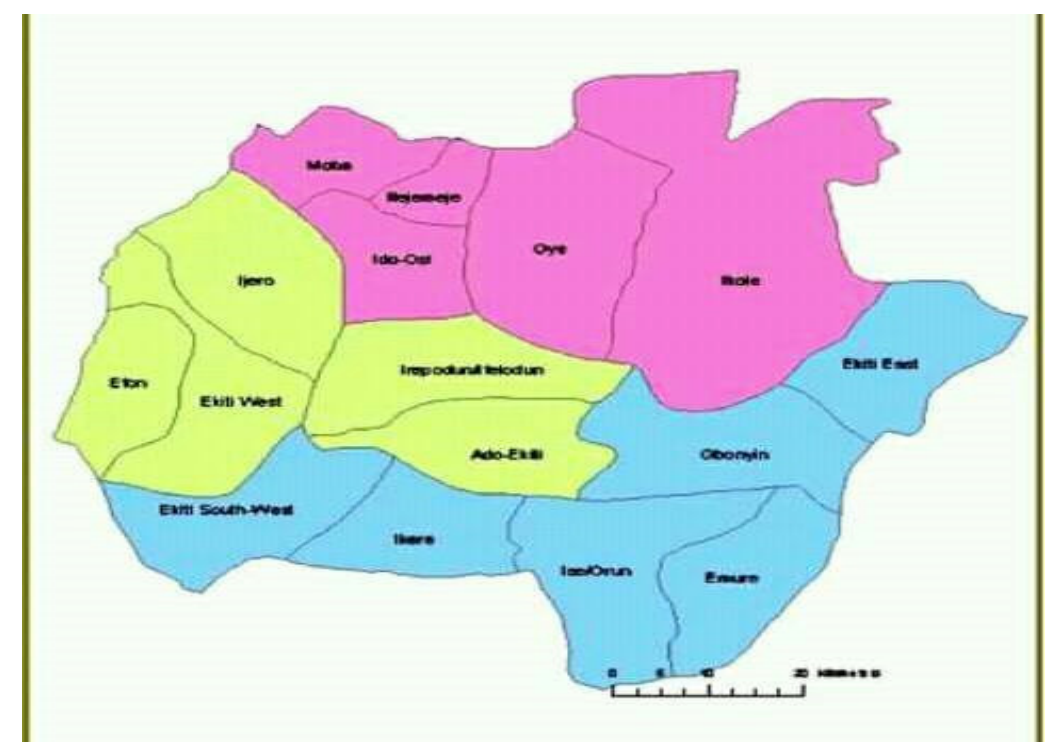

Figure 1.1 The Map of Ekiti State

Source: NAERLS and NPAFS 2010.

\subsection{Sampling Technique}

A multi-stage sampling technique was used in the selection of respondents. At the first stage, Five (5) LGA were randomly selected from the sixteen LGA in the state. At the Second stage, 6 towns were randomly selected from each of the 5LGA. This gives a total of 30 communities. Finally, 6 women cassava processors were purposively selected from each town using snowball method, giving a total sample size of 180 women cassava processors.

\subsection{Data Collection and Data Analysis}

Data were collected from 180 women cassava processors selected through multi-stage sampling method. Five local government areas were randomly selected, 6 towns and villages randomly selected and 6 women cassava processors were purposively selected making a total 


\section{Macrothink}

of 180 respondents in all. Structured questionnaire were administered on the respondents with the assistance of hired enumerators. Data were analysed using descriptive statistics; Friedman Ranking Analysis (FRA) was used for ranking the investment preference while Probit model was used for estimating factors influencing investment decision

\subsection{Friedman Ranking}

The savings' avenue were ranked using Friedman Ranking analysis with the implicit model specified as

$$
F_{n}=\frac{12}{r c(c+1)} \sum_{i=1}^{\varepsilon} R f-3 r(c+1)-------------(1)
$$

Where

$\mathrm{Rn}^{2}=$ square of the total of the ranks for group $\mathrm{n}(\mathrm{n}=1,2 \ldots)$

$\mathrm{r}=$ number of blocks

$\mathrm{c}=$ number of groups

\section{Probit Model}

This was used to analyse the factors influencing the investment decision of the respondents according to Mahmood and Cheema(2004) and Awunyo (2012), Probit model has the advantage of predicting the probability of investment decision and also guarantees that the estimated probabilities lie between $0-1$. It can also solve Heteroskedasticity problems. The implicit probit model is specified as

$$
\begin{aligned}
& P_{t}=P\left(y_{t}^{b}<y_{t}\right) \\
& P_{l}=P\left(y_{t}^{2}<\beta_{i}+\beta_{1} x_{t j}\right)=F\left(y_{t}\right) \\
& R_{1}=P\left(\sigma_{\alpha}\right)=\frac{1}{\sqrt{2 \pi}} \int_{-\pi}^{s p} \theta \frac{s^{2}}{2} d s
\end{aligned}
$$

Where $\mathrm{Pi}$ is the probability that a processor will invests or not; $\mathrm{S}$ is a random variable normally distributed with a mean zero and unit variance yi is the dependent variable (invest); $\mathrm{yi}^{*}$ is the threshold value of the dependent variable. To obtain an estimate of the index $\mathrm{Zi}$, the inverse of the normal cumulative function is used and is given as:

$$
y_{t}=F^{-t}\left(F_{t}\right)=\beta_{0}+\beta_{1} x_{1}+\beta_{t}
$$

The Probit model used in analyzing the factors is explicitly stated as follows:

$$
\mathrm{P} 1=\beta 0+\beta 1 \mathrm{x} 1+\beta 2 \times 2+\beta 3 \times 3+\beta 4 \times 4+\beta 5 \times 5+\beta 6 \times 6+\beta 7 \times 7+\varepsilon \mathrm{i}
$$

Where:

$\mathrm{Pi}=$ if invested $(1)$ or otherwise $(0)$

$\mathrm{x}_{1}=$ Age of respondent in years

$\mathrm{x}_{2}=$ Annual Income ( 
$\mathrm{x}_{3}=$ Return on investment ( 1 if yes) otherwise $(0)$

$\mathrm{x}_{4}=$ Knowledge about investment ( 1 if yes) otherwise ( 0 )

$\mathrm{x}_{5}=$ Access to credit ( 1 if yes) or (0) otherwise

$\mathrm{x}_{6}=$ Household size in numbers

$\mathrm{x}_{7}=$ Marital Status ( 1 if married) or (0) otherwise

$\beta \mathrm{s}=$ coefficients to be estimated

$\varepsilon i=$ is the error term.

\section{Result and Discussion}

\subsection{Socio-economic Characteristics of Women Cassava Processors in Ekiti State}

The respondents were still young judging by their age. With mean age of 36.5years and maximum age of 53years they would still have enough strength to carry out their processing activities. This is corroborated by Alao, Torimiro and Ayinde (2016). Equally, the processing experience of the respondents would encourage improved cassava processing activities. The mean processing experience was 10.6years while maximum was 21 years (Table 1). As indicated in Table 1, 73\% of them had acquired formal education with $13.3 \%$ attaining tertiary institution. However, about $27 \%$ of the respondents had no formal education. This educational status would encourage the adoption of modern processing technologies if and when introduced. Similarly, the respondents have a large household size of $8-16$. This could be advantageous to processors if the adolescent members are willing to provide family labour otherwise they could constitute serious constraints to the provision of adequate investment funds to farm enterprises.

Table 1. Socio - economic Distribution of Women Cassava Processors in Ekiti State

\begin{tabular}{lllllll}
\hline Variables & Frequency & Percentage & Mean & $\begin{array}{l}\text { Standard } \\
\text { deviation }\end{array}$ & $\begin{array}{l}\text { Mini } \\
\text { mum }\end{array}$ & $\begin{array}{l}\text { Maxi } \\
\text { Mum }\end{array}$ \\
\hline Age & & & 36.5 & 8.979 & 20 & 53 \\
$20-30$ & 34 & 18.9 & & & & \\
$31-40$ & 65 & 36.1 & & & \\
$41-50$ & 55 & 30.6 & & & \\
$\geq 50$ & 26 & 14.4 & & & \\
Total & 180 & 100 & & & \\
Processing experience & & & & & \\
$\leq 5$ & 30 & 16.7 & & & \\
$6-10$ & 69 & 38.3 & & & \\
$11-15$ & 54 & 30 & & & \\
$\geq 15$ & 27 & 15 & & & \\
Total & 180 & 100 & & & \\
Educational level & & & & & \\
No formal education & 48 & 26.7 & & & \\
Primary & 73 & 40.6 & & & \\
Secondary & 35 & 19.4 & & & \\
Tertiary & 24 & 13.3 & & & \\
Total & 180 & 100 & & & \\
\hline
\end{tabular}




\begin{tabular}{|c|c|c|c|c|c|c|}
\hline Household size & & & 8 & 3.78 & 2 & 16 \\
\hline$\leq 3$ & 28 & 15.6 & & & & \\
\hline $4-8$ & 90 & 50 & & & & \\
\hline $9-12$ & 33 & 18.3 & & & & \\
\hline$\geq 12$ & 29 & 16.1 & & & & \\
\hline Total & 180 & 100 & & & & \\
\hline
\end{tabular}

Source, field survey 2017

\subsection{Annual Income Distribution of Women Cassava Processors in Ekiti State}

The Cassava processor in the study area generated their income from two main sources, cassava processing and other sources such as farming, trading etc. however cassava processing was their major source, but they diversify during the off-season for additional income. Modal income generated from cassava processing was $\$ 100,000-250,000$ annually (Table 2) with mean income of $\$ 195,000$ while minimum and maximum income generated annually were $\$ 75,000$ and $\$ 620,000$ respectively. This implies that the annual income was considerable and could still allow some savings and investment if properly managed.

Table 2. Annual Income Distribution of women cassava processors in Ekiti State

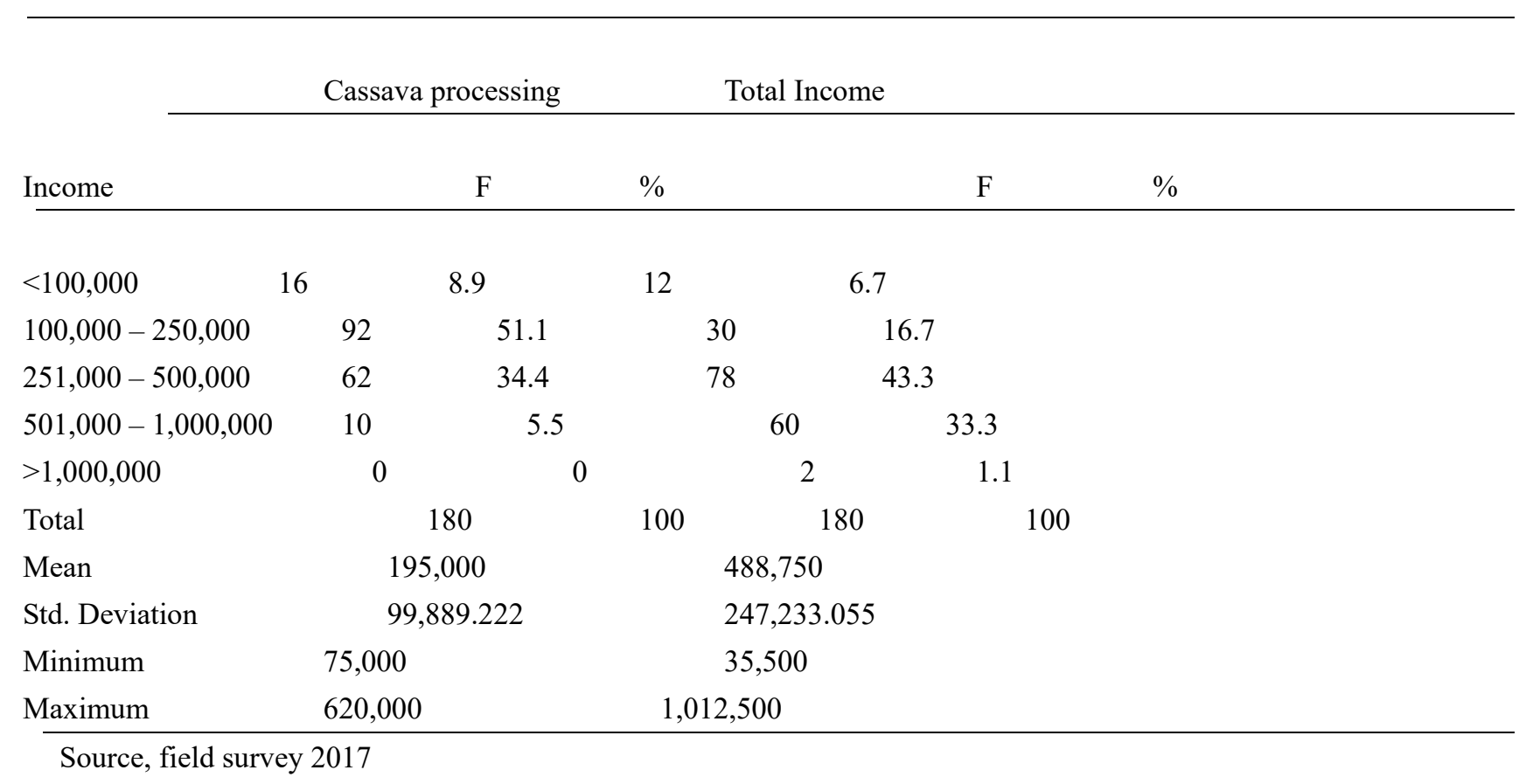

4.3 Friedman Ranking Analysis of Choice of Investment of Women Cassava Processors in Ekiti State

The respondents invest in different forms; the result of their choice of investment was presented in Table 3 based on their mean rank score using Friedman ranking analysis. From the findings, Crop production with the mean score of 5.85 was the most preferred investment choice by the respondents. This can be attributed to the fact that crop farming has low risk 
and low capital intensive compared to other choice of investment available to other respondents, it is also a regular source of food for the family. Besides, it is becoming a way of life in a typical agrarian environment like Ekiti State and fourthly it does not call for the attention throughout the year particularly tree crops and therefore give room for income diversification. Petty trade with mean score of 4.77 was the second choice of investment by the respondents. This can be credited to quick return on investment associated to it when compared to other forms of investment. Livestock at 3.96 mean score and fisheries at 3.42 mean score were ranked third and fourth respectively by the respondents. This can be attributed to the technicality and high risk involved. Similarly, Non farming activities such as purchase of farm land produce at 3.49 mean score, purchase of land and building properties such as house, shops etc. at 3.75 mean score was ranked fifth and sixth respectively. This can be attributed to incessant land dispute typical of land owners in the study area. Meanwhile, purchase of processing equipment/building of agriculture processing unit at 3.75 mean score was ranked seventh Investment avenue by the respondents. This could be because of high capital intensive nature of the investment choice.

Table 3. Rank of Choice of investment of women cassava processors in Ekiti State

\begin{tabular}{lll}
\hline Choice of investment & Mean Rank & \\
\hline Crop Production & 5.68 & $1 \mathrm{st}$ \\
Trading & 4.77 & 2nd \\
Livestock production & 3.96 & $3 \mathrm{rd}$ \\
Fish farming & 3.49 & 4 th \\
Purchase of farmland produce & 3.42 & 5 th \\
Land and building of properties & 3.36 & 6 th \\
Purchase of Processing equipment & 3.34 & 7 th \\
\hline
\end{tabular}

Source: Field survey, 2017.

\subsection{Propensity to Invest of Women cassava processors in Ekiti State}

The processors were asked to give what they were able to invest from both processing and off-processing income and the result was presented in Table 4. Results show that the modal amount invested was $\$ 151,000-250,000$ annually while the mean investment was $\$ 160,300$ and maximum investment was 560,000 per annum. However, average propensity to save (APS) was approximately 0.33 implying that 33 percent of the annual income of the respondents was invested.

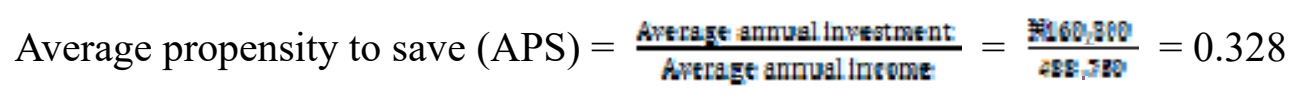

Also, the Marginal propensity to invest (MPI) of respondents was analyzed using linear regression and the results were presented in Table 5. The results show that the Marginal 


\section{Macrothink}

International Journal of Social Science Research

ISSN 2327-5510

2018, Vol. 6, No. 2

propensity to invest is equal to $¥ 0.228$ for every increase in the income i.e. a $¥ 1$ increase in income leads to 0.228 increase in amount invested by the respondents. The result indicates that investment potentials exist among the women cassava processors in the study area.

Table 4. Amount invested by the respondents

\begin{tabular}{|c|c|c|c|}
\hline \multicolumn{2}{|l|}{ Investment } & Frequency & Percentage \\
\hline \multicolumn{3}{|c|}{ No Investment } & 28 \\
\hline \multicolumn{4}{|l|}{15.8} \\
\hline \multicolumn{2}{|l|}{$<50,000$} & & 8 \\
\hline \multicolumn{4}{|l|}{4.4} \\
\hline 50,000 & $-\quad 150,000$ & & 15 \\
\hline \multicolumn{4}{|l|}{8.2} \\
\hline 151,000 & $-\quad 250,000$ & & 60 \\
\hline \multicolumn{4}{|l|}{33.3} \\
\hline 251,000 & $-\quad 350,000$ & & 42 \\
\hline \multicolumn{4}{|l|}{23.3} \\
\hline 351,000 & $-\quad 500,000$ & & 18 \\
\hline \multicolumn{4}{|l|}{10.0} \\
\hline \multicolumn{2}{|l|}{$>500,000$} & & 9 \\
\hline \multicolumn{4}{|l|}{5.0} \\
\hline \multicolumn{2}{|l|}{ Total } & & 180 \\
\hline \multicolumn{4}{|l|}{100} \\
\hline \multicolumn{2}{|l|}{ Mean } & 160,300 & \\
\hline \multicolumn{2}{|c|}{ Std deviation } & 48223.6 & \\
\hline \multicolumn{2}{|l|}{ Minimum } & 30,000 & \\
\hline \multicolumn{2}{|l|}{ Maximum } & 560,000 & \\
\hline
\end{tabular}

Source, field survey 2017

Table 5 Marginal Propensity to Save (MPS) of women cassava processors in Ekiti State

\begin{tabular}{lllll}
\hline Variables & \multicolumn{1}{c}{ coefficients } & Std. Error & T - values \\
\hline Constant 28779 & 9554.582 & 3.012 & & \\
Annual income & $0.228^{*}$ & 0.0267 & 8.483 & \\
R2 28.8 & & & \\
Adjusted R2 28.4 & & & \\
\hline
\end{tabular}

Source: Field survey 2017.

Note $*$ means correlation significant at $1 \%$ level

4.5 Analysis of Factors influencing Investment Decision of Women Cassava Processor in Ekiti State

The results of the Probit regression analysis on the factors influencing investment decision of women cassava processors is presented in Table 6. From the findings, Age, Household size, Knowledge about investment has a negative relationship with the respondents' decision to 
invest. As the household size increases by 1 , the chances that the respondents will invest decreases by 0.056 that is the higher the household size, the less likely the respondents invest. This is evident because a majority of the respondents have a large household sizes and will possibly spend more of their income on personal well-being and household consumption rather than investment. Also, the negative relationship between age and investment decision indicates that as the Age of the respondents increases, the probability that the respondents to invest decreases by 0.009 . The aptness of the respondents to invest as age increase could be attributed to some needs that may arise with age such as general health care. Meanwhile, the more the respondents have knowledge about a given investment, the lesser their willingness to invest i.e. the probability to invest decreases by 0.0418 . This could be attributed to the low risk tolerance level, and lack of exposure of the respondents.

On the other hand, Annual income, Access to credit, Return on Investment and Marital status has a positive relationship with the respondents' investment decision. As the Annual income increases by 1 , the probability that the respondents will invest increases by 0.1288 (that is the higher the income of the respondents, the higher their marginal propensity to invest). This could be attributed to the fact that respondents with higher income level will have a higher tolerance for investment risk. Also, the more the respondents have access to credit, the higher their willingness to invest i.e. the probability to invest increases by 0.1302 . This is apparent because the majority of the respondents participate in various cooperative societies that gives them low interest loans which they invested.

Furthermore, the more income the respondents gained from previous investment, the more they are willing to invest i.e. 1 increase in the ROI increases the probability to invest by 0.9017. This is because the higher the profit earned on investment, the more likely the respondents will invest. Meanwhile, marital status has positive relationship with investment. It implies that married cassava processors have higher aptness to invest to be able to support their husband's income needs. Return on investment was significant at 1\%; household size and annual income were significant at $10 \%$ indicating that these variables are significant in the respondents decision to invest.

Table 6. Probit Regression Analysis of Factors influencing Investment Decision of Women Cassava Processor in Ekiti State

\begin{tabular}{lclll}
\hline Variables & Coefficient & Std. Error & $\mathrm{Z}$ & $\mathrm{P}>/ \mathrm{z} /$ \\
\hline Constant & 1.1285 & 0.836738 & 1.3487 & 0.177 \\
Age & -0.0094 & 0.0133462 & -1.4356 & 0.402 \\
Household Size & $-0.0566^{*}$ & 0.0331005 & -1.2483 & 0.070 \\
Annual Income & $0.1288^{*}$ & 0.329962 & 0.0150 & 0.068 \\
Access to credit & 0.1302 & 0.296067 & 0.0051 & 0.637 \\
Return on Invest. & $0.9017^{* * *}$ & 0.244892 & 3.3220 & 0.000 \\
Knowledge about Investment & -0.0418 & 0.528635 & -0.7474 & 0.920 \\
Marital Status & 0.0640 & 0.127153 & 0.2984 & 0.612 \\
\hline
\end{tabular}




$\begin{array}{ll}\text { Number of observations } & 180 \\ \text { McFadden R-Squared } & 0.076357 \\ \text { Mean Dependent Variable } & 0.822222 \\ \text { Log likelihood } & -77.80889 \\ \text { LR chi2(7) }= & 16.867 \\ \text { Prod.>chi2(2) } & 0.0001 \\ \text { Pseudo R2 }= & 0.0448\end{array}$

Source:Field survey2017.

Note: $*$ and $* * *$ represent $1 \%$ and $10 \%$ significant levels respectively

4.6 Relationship Between Factors Influencing Investment Decision and Marginal Propensity to Invest of the Woman Cassava Processors

The result in Table 7 shows the Pearson correlation coefficient between factors influencing investment decision and marginal propensity to invest of the woman cassava processors. From the result, marital status has a positive but no significant effect with the respondents MPI. The negative significant relationship between Annual income and the respondents MPI indicates that $¥ 1$ decrease in the respondent income reduce their MPI by $¥ 0.211$ while positive significant relationship between Return on investment (ROI) and the respondents MPI indicates profit made on a particular investment increase their MPI by $\$ 0.231$. However, Age, Household size, Access to credit, Knowledge about investment and annual saving have negative and no significant relationship with the MPI of the respondents. The null hypothesis that there is no significant relationship between factors influencing investment decision and marginal propensity to invest of the woman cassava processors was annulled.

Table 7. Pearson correlation coefficient between factors influencing investment decision and marginal propensity to invest of the woman cassava processors

\begin{tabular}{ll}
\hline Variables & MPI \\
\hline Age & -0.013 \\
& $(0.862)$ \\
House hold size & -0.081 \\
& $(0.279)$ \\
Access to credit & -0.064 \\
Marital status & $(0.397)$ \\
& 0.006 \\
Knowledge about investment & $(0.933)$ \\
& -0.125 \\
Annual income & $(0.094)$ \\
Annual savings & $-0.211^{*}$ \\
& $(0.005)$ \\
& -0.121 \\
\end{tabular}


Source: Field survey, 2017.

Note * means correlation significant at $1 \%$ level

\section{Conclusion, Policy Implications of Major Findings and Recommendations}

The age distribution of the respondents was skewed towards the youths. Since cassava processing in the study area relies heavily on human muscles, the respondents may have sufficient stamina to carry out processing activities and may be willing to earn their highest possible income from processing. This is corroborated by the considerable annual income realized from cassava processing. The marginal and average propensities to invest showed that the processors had the potentials to invest and were willing to invest. Crop production was their most preferred investment, followed by trading and livestock production. Although this is an indication that respondents were interested in agriculture, but their keen interest in trading and their unwillingness to invest on processing equipments is worrisome and may pose a serious threat to the sustainability of cassava processing in the study area. This is because investing in trading is an indication of income diversification tendency. It's therefore recommended that modern processing facilities should be subsidized to reduce the processing cost, encourage future investment on them, reduce drudgery, increase value addition, income and consequently increased investment. Secondly, soft loans free of collateral should be giving to the processors to facilitate purchase of processing equipments, develop and expand their processing sheds.

\section{References}

Ajayi, C. A. (1998). Property Investment Valuation and Analysis, De-Ayo publication, Ibadan. pp 15-16.

Alao, O. T., Torimiro, D. O., \& Ayinde J. O. (2016). Perception of Youth Roles in Agricultural Innovation Management System among Arable Crop Farmers in Farming Communities of Osun State, Nigeria

Awunyo, V. D. (2012). Determinants of Loan Repayment Default among Farmers In Ghana. Journal of Development and Agricultural Economics, 4, 339-345.

Bairagi, U., \& Rastogi, C. (2003). An Emperical Study of Saving Pattern and Investment Preferences of Individual Household with Reference to Pune City. ASM's International E-Journal of Ongoing Research in Management and IT., 1-11.

Brata, A. G. (1999). Household Saving Behavior: The case of rural industry in Bantul. CSIS 28(1), 75-86.

FAO. (2004). Cassava industrial revolutionin Nigeria. Retrieved from www. Fao.org/docrep007/y5548e/y5548 e07htm

FAO (2003): Food and Agriculture Organization (FAO). Retrieved from www.fao.org 
Jhingan, M. L. (1997). Macro-Economic Theory. Uringda Publications P, Ltd Pp 134 - 149.

Mahmood, K., \& Cheema, M. A. (2004). Determinants and Maximum Likelihood Functions of Juvenile Crime in Punjab, Pakistan. International Journal of Agriculture \& Bialogy, 5, 918-921.

Odoemenem, I. U., Ezihe, J. A. C., \& Akerele, S. O. (2013). Saving and Investment Pattern of Small-Scale Farmers of Benue State, Nigeria. Global Journal of Human Social Science Sociology and Culture, 13(1), 7-12.

Oluwakemi A.O (2012) Saving Behavior of Rural Households in Kwara State, Nigeria. African Journal of Basic \& Applied Sciences 4 (4): 115-123.

Oluwasola, O., Kassali, R. and Amusan, C.A. (2012). Factors Enhancing Investment and Farm Capitalization in Small Holdings in Nigeria: Policy Implications for Transforming the Agricultural Sector. International Journal of Agriscience. 2(3): 265-279

Osaka J.I. (2006) An analysis of savings and investment Behaviour of farmers in giwa and Sabon-gari local government areas of Kaduna state.

Onyemauwa C.S. (2012) Analysis of Women Participation in Cassava Production and Processing in Imo State, Southeast Nigeria. Journal of Economics and Sustainable Development ISSN 2222-1700 (Paper) ISSN 2222-2855 (Online) Vol.3, No.5, 2012

Phillips,T.P, Taylor,D.S, Sanni,L, Akoroda, M.O (2004). “A cassava Industrial Revolution in Nigeria: The Potential for a new Industrial Crop". International Institute of Tropical Agriculture, Ibadan, Nigeria". International Fund for Agricultural Development, Food and Agriculture Organization of the United Nations, Rome, Italy.

Shitu, G.A. (2012). Rural Households Income and Savings pattern in South- Western Nigeria. Agricultural journal. 7(3): 172-176

Singh D.E.N (2011) "Rural Savings and its Investment in Manipur, A Case Study of Formal Finance vis-à-vis Marups,’Management Convergenc., vol..2, no.2, pp. 10-30, 2011.

\section{Copyright Disclaimer}

Copyright for this article is retained by the author(s), with first publication rights granted to the journal.

This is an open-access article distributed under the terms and conditions of the Creative Commons Attribution license (http://creativecommons.org/licenses/by/3.0/). 